
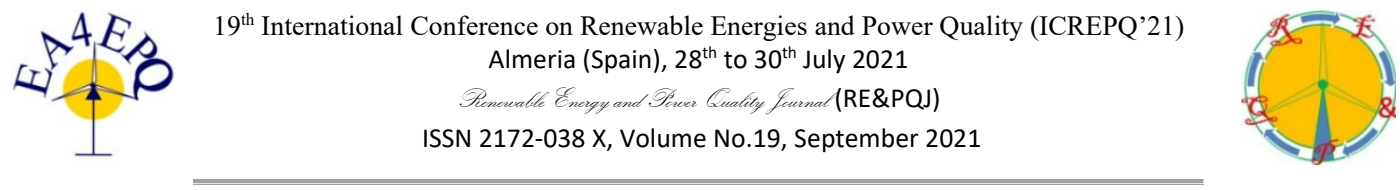

\title{
The Contribution of Experimental Energy Facilities to the Achievement of SDG in their Environment: The Case of IFMIF-DONES
}

\author{
Rafael Esteban López ${ }^{1}$; Zaida Troya ${ }^{1}$; Virginia Fernández-Pérez ${ }^{1,2}$; Antonio Peña- \\ García $^{3, *}$ \\ 1"DONES Preparatory Phase" (CE Ref. 870186) Project \\ Vicerrectorate of Research - University of Granada, 18071 Granada, Spain \\ ${ }^{2}$ Dpt. Business Organisation, Faculty of Economics and Business \\ University of Granada, 18071 Granada, Spain \\ Mail: vfperez@ugr.es \\ ${ }^{3}$ Department of Civil Engineering \& Co-PI UGR "DONES Preparatory Phase" (CE Ref. 870186) \\ University of Granada, 18071 Granada, Spain \\ *Correspondence: pgarcia@ugr.es
}

\begin{abstract}
:
Scientific infrastructures are known to have a deep impact from two main perspectives: the finality they were designed to, and other collateral impacts like changes in the economic geographic land where they are settled. However, the effects from other perspectives like social evolution and contribution to Sustainable Development have not been studied in depth yet. In this work, the effects of the implementation of the "International Fusion Materials Irradiation Facility - Demo Oriented NEutron Source" (IFMIF-DONES) in a rural area in the Southern Spain will be discussed.
\end{abstract}

Keywords: Sustainable Development, Global Sustainability, Scientific Infrastructures, PostCovid Scenario, Clean Energy

\section{Introduction}

A new perspective on Science and Technology projects that focuses more on long-term aspects and the consideration of other variables in terms of profitability has been a constant trend for about 40 years instead of the absolutely resultsoriented philosophy which started with the Industrial Revolution. The results from the Industry are no longer exclusively focused on the economic benefits, but also on other outcomes like people's well-being and activity impact from other perspectives [1].

One remarkably important milestone between both tendencies can be found in Brundtland Report: "Sustainable development must meet the needs of current generations without compromising the ability of future generations to meet their own needs" [2].

The recent compilation of the "Sustainable Development Goals" (SDG) [3], which summarizes and attempts to channel the efforts towards a better world, is fully applicable to the technological development and the infrastructures built to achieve it. The actions and projects with strong technological background should bring highly qualified employment, investments and economic prosperity for the territory contributing to the achievements of the SDG.

Summary of the SDG and their official labels: 1. No Poverty; 2. Zero Hunger; 3.Good Health and Well-being; 4. Quality Education; 5. Gender Equality; 6. Clean Water and Sanitation; 7. Affordable and Clean Energy; 8. Decent Work and Economic Growth; 9. Industry, Innovation and Infrastructure; 10. Reduced Inequality; 11. Sustainable Cities and Communities; 12. 
Responsible Consumption and Production; 13. Climate Action; 14. Life Below Water; 15. Life on Land; 16. Peace and Justice Strong Institutions; 17. Partnerships to achieve the Goal.

Nowadays it is clearly understood and accepted that [4-5]:

1) The environmental impact caused by the demand of natural resources must be decreased as much as possible.

2) Productive models must be more and more sustainable according to the abovementioned philosophy of Brundtland report.

3) Sustainable Development requires organizational structures that must be adapted accordingly.

The so called "Circular Economy", more and more deeply present in engineering processes going from design to decommissioning [6] is a good example.

Attending to its significance and dimension (environmental, social and economic) [7], it is clear that SDG cannot be achieved from isolated perspectives, and some transversal branches of Science and Technology closely related to them, are claiming for global visions [8].

\section{IFMIF-DONES: the key milestone towards the use of fusion energy}

The energy binding the nuclei in atoms has been used from the 1940's in the process called "nuclear fission", that is, heavy nuclei like Uranium 235 release energy when they are broken by an incident neutron. In Spain, 20\% of the produced energy is achieved with just seven fission reactors [8]. In spite of its high efficiency, fission requires the use, management and storage of hazardous materials. On the other hand, nuclear Fusion is expected to be a cleaner, safer and much more efficient source of energy, which makes it the ideal alternative to provide sustainable energy that does not harm the environment and ensures economic growth for mankind. Current works to control fusion include thousands of scientists around the world.

Currently under construction in Cadarache (France) [9]. ITER (www.iter.org) is the most ambitious project up to date developed in order to solve the two main technical limitations of fusion:
This research presents and analyses the situation and potential effects of critical scientific and technological infrastructures on their near geographical framework from the perspective of Global Sustainability and SDG, taking as example and guide the "International Fusion Materials Irradiation Facility - Demo Oriented NEutron Source" (IFMIF-DONES). In addition to the main objective of this project, which is to succeed in providing some key milestones from other parallel perspectives on the road to clean and nearly limitless energy from nuclear fusion, it aims to contribute fully to sustainable regional development in the above-mentioned broad contexts of the Brundtland Report and the SDGs. (see Figure 1).

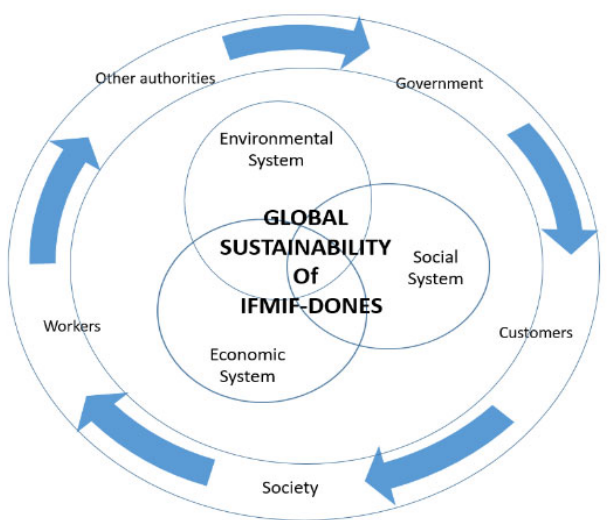

Fig. 1 The role of IFMIF-DONES on Global Sustainability

1) Fussing light elements requires working in extreme conditions around 100 million ${ }^{\circ} \mathrm{C}$. 2) The neutrons arising from the nuclear reaction are extremely difficult to control.

The fact that the ITER Members are China, the European Union, India, Japan, Korea, Russia and the United States, shows the high strategic interest of this experimental infrastructure and the geopolitical importance of fusion control.

At the same time IFMIF-DONES (www.ifmifdones.org) [10], is called to solve the second shortcoming from a more specific perspective.

The target of IFMIF-DONES is to obtain neutrons like those to be produced in real fusion reactions without reaching the extremely high temperatures of these reactions; it is therefore a facility where the neutrons that we want to learn how to stop will be produced. The study of their effects on different materials will be developed in order to select the ones that best withstand that flux of neutrons to use them to build the fusion reactors in the future. 
IFMIF-DONES has three main parts:

1) Particle accelerator, where deuterons (nuclei of hydrogen with one proton and one neutron) will be accelerated to very high speed. In a second phase, two parallel accelerators will work simultaneously.

IFMIF-DONES is expected to be installed in Escúzar, a town in the Province of Granada (South of Spain), which is a rather economically depressed area.

An expected budget of $700 \mathrm{M} €$ (funded by the Central Government of Spain and the Regional Government of Andalusia), makes it the largest scientific infrastructure ever built in Spain. Most of these national funds will come from the European Regional Development Fund (ERDF). In addition, other funds will come from organizations like EUROfusion and other European programs. A first already transferred budget of $32.6 \mathrm{M} €$ to the main spanish implementing institutions of IFMIF-DONES: CIEMAT (Centro de Investigaciones Energéticas, Medioambientales y Tecnológicas) and the University of Granada is being earmarked to start the construction and launch the first actions. In addition, 4 more M€ have been provided by the European Strategy Forum on Research Infrastructures (ESFRI).

It is interesting to remark that there were other candidates (Poland and Croatia) whose economic level is lower than the European average to host IFMIF-DONES. Finally, Escúzar was appointed as EU candidate to host IFMIF-DONES, a good indication of the potential of critical technological infrastructures as a motor for regional development.
2) Liquid Lithium target, where the accelerated deuterons will impact producing nuclear reactions whose product are neutrons with the same energy of those created in fusion.

3) Test module, where different materials will be placed and irradiated with the neutrons.

\section{Effects of peripheral large scientific infrastructures on social and territorial sustainability}

The total sum of the investment planned for the first phase of construction and IFMIF DONES (729.57M€) which will be executed over approximately 9 years will have a very positive socioeconomic and environmental impact .Thus, the quality management of large projects is linked to sustainability and the development of a society and vice versa [11].

The key to achieving the sustainable development of a territory (territorial sustainability) is an understanding and modeling of its identity [11-13]. Sustainable territorial development can refer to different levels, and in particular to regional and local or relative to a country, a continent or the entire world economy. Many researchers around social sustainability have focused mainly on the urban studies from both academic and policy perspectives [14-16].

The purpose of this work is to review the social sustainability from the perspectives of peripheral development. As Ezcúzar and its province, Granada, have quite specific socioeconomic indicators. Hence, it is necessary to work in this dependent context, due to influence of the relevance of the project through the perspective of social and territorial sustainability. Table 1 compares both cities in terms of population and Economy.

Table 1. Comparison between the village of Escúzar and the city of Granada (Province Capital). Source: Instituto de Estadística y Cartografía de Andalucía. 2019 


\begin{tabular}{|c|c|c|}
\hline & Granada & Escúzar \\
\hline Total population & 232,462 & 791 \\
\hline $\begin{array}{l}\text { Population under } 20 \text { years old } \\
(\%)\end{array}$ & 18.3 & 17.7 \\
\hline $\begin{array}{lll}\text { Relative increase } & \text { of } \\
\text { population in } 10 \text { years } & \\
\end{array}$ & -0.8 & -4.7 \\
\hline Public infrastructures & $\begin{array}{l}155 \text { schools, } 10 \text { libraries, } 21 \text { medical centers, } 1 \\
\text { public university. }\end{array}$ & $\begin{array}{l}1 \text { school and } 2 \text { nurseries. } 1 \\
\text { medical center. }\end{array}$ \\
\hline Economy & $\begin{array}{l}\text { Wide variety of services: } 22917 \text { business with } \\
\text { economic activity and } 13406 \text { places to host } \\
\text { (tourism). Some agriculture and industry. }\end{array}$ & $\begin{array}{l}\text { Mainly agriculture. Recently, } \\
\text { some industry. }\end{array}$ \\
\hline Rate of unemployment & 23.2 & 23.8 \\
\hline
\end{tabular}

\section{Global effects of IFMIF-DONES}

Given its main role in the energy future of Mankind, IFMIF-DONES is expected to have effects at several levels [1]:

(1) Global level: IFMIF-DONES will permit the development of fusion energy, which is expected to have a very high efficiency producing energy from non-hazardous fuels.

(2) European Union level: The EU is one of the parts of the Broader Approach with

Japan. The major part of the funds financing IFMIF-DONES come from European programs. Therefore, the successful construction and operation of IFMIF-DONES will be a success for the European scientific policy.

(3) Spanish level: The expected location for IFMIF-DONES is in the South of Spain. The Spanish Government is dedicating a major part of its EFDR to fund IFMIF-DONES. In this scenario, the increase in the number of contracts and the attraction of highly specialized construction and technological enterprises are a very worthy output of the project for Spain. Furthermore, the rise of Spanish research centers in important indicators is another attractor and motor for progress.

(4) Regional level: The Regional Government of Andalusia is carrying out the first investments of the project implementation at $50 \%$ with the Central Government. The origin of these funds is mainly the EFDR with some additional investment from its own budget. The expected impact will be both financial and scientific, but there is one particularity: the IFMIF-DONES project can become the needed boost for the shift of a mainly tourism-based economy to a knowledge-based one.
(5) Local impact: The territory where IFMIFDONES is expected to be built and developed has high dependence on agriculture, tourism, construction, low rate of industrialization and big companies and a big cultural gap between young and older people, high rates of unemployment.

In this particular territorial framework, the potential territorial yields of the project are:

(1) Implementation of new high-technology private companies and stimulation of existing ones to work as suppliers during construction and operation of the facility.

(2) Stimulation of regional construction companies.

(3) Creation of highly qualified jobs for local graduates and additional services jobs for nongraduate local workers currently in unemployment.

(4) Creation of new lines of research complementary to the ones of the University and the research centers in the area.

(5) Improvement of auxiliary infrastructures.

Hence, we are considering a strategic infrastructure not only in terms of the outcomes of the experiments carried out, or in the improvements in terms of energy efficiency and environmental impact, but also from a social and economic point of view. As shown, its impact is transversal and at different levels goes from the supranational bodies to the local Administrations.

In addition, all the analyzed effects correspond to Sustainable Development Goals (SDG), which clearly show that the installation of this kind of experimental infrastructures also allows the achievement of these strategic goals. 


\section{Conclusions}

The International Fusion Materials Irradiation Facility-DEMO Oriented Neutron Source (IFMIF-DONES) is a unique experimental facility to be implemented in Escúzar (Granada, Spain) whose target is the production of fusionsimilar neutrons to irradiate different materials in order to decide which ones to use in the future fusion reactors. This emblematic project will be more than a key milestone in the long way to clean and almost unlimited nuclear energy. The decision to install this facility in a rural and peripheral zone of a not highly industrialized country brings new opportunities and a fast-track to a quick but Sustainable Development of the zone according to the Sustainable Development Goals (SDG).

The reason is that Sustainable Development transcends energy, directly impacting people's well-being, quality of life, qualified work, culture and many other essential aspects of life not directly related to the classical approach focused on environmental protection.

\section{Funding}

This work was supported by the European Commission as part of the Project "DONES Preparatory Phase" (Ref. 870186).

\section{References}

[1] Fernández-Pérez, V.; Peña-García, A. The Contribution of Peripheral Large Scientific Infrastructures to Sustainable Development from a Global and Territorial Perspective: The Case of IFMIF-DONES. Sustainability2021, 13, 454.

https://doi.org/10.3390/su13020454.

[2] World Commission on Environment and Development, 1987. Our Common Future. Oxford University Press, Oxford. ${ }^{1}$

[3] United Nations Division for Sustainable Development Goals (DSDG). https://sustainabledevelopment.un.org/

[4] Henriques, A.; Richardson, J. The Triple Bottom Line: Does It All Add Up? Assessing the Sustainability of Business and CSR. Earthscan: London, UK, 2004.

[5] Cardillo, E.; Longo, M.C. Managerial Reporting Tools for Social Sustainability: Insights from a Local Government Experience.Sustainability2020, 12, 1-23. https://doi.org/10.3390/su12093675.
The consequences of building IFMIF-DONES in Escúzar are still to be understood in depth and, of course, will not be known for decades. Furthermore, the impact of IFMIF-DONES in the postCOVID era and the deviations with respect to the initially planned economic and social parameters are also a great challenge.

But we already have some clues because the social and economic situation of the zone is well known, and its shortcomes are complementary with the opportunities that IFMIF-DONES will bring.

Concretely, the conversion of a rural and touristic economy into a knowledge-based one, the increase in attachment of young and highly educated people to their homeland instead of emigrating to the big cities inside and outside Spain are main effects that will surely arise.

In the next years we will have more certainties and a more complete knowledge of the impact of this kind of installations in poorly developed zones as well as the synergies of this kind of technology with the achievement of the Sustainable Development Goals.

[6] Molina-Moreno, V.; Leyva-Díaz, J.C.; Sánchez-Molina, J.; Peña-García, A. Proposal to foster sustainability through circular economybased engineering: A profitable chain from waste management to tunnel lighting. Sustainability2017, 9, 2229.

https://doi.org/10.3390/su9122229.

[7] Elkington, J. Accounting for the triple bottom line. Measuring Business Excellence1998, 2, 18-22.

https://doi.org/10.1108/eb025539.

[8] Peña-García, A; Salata, F. The perspective of Total Lighting as a key factor to increase the Sustainability of strategic activities. Sustainability2020, 12, 2751. https://doi.org/10.3390/su12072751.

[9] https://www.iter.org/proj/inafewlines (Last accessed on 2020 March 15th).

[10] https://ifmifdones.org/ (Last accessed on 2021 March $\left.15^{\text {th }}\right)$. 
[11] Hall, J.; Matos, S.; Sheehan, L.; Silvestre, B. Entrepreneurship and Innovation at the Base of the Pyramid: A Recipe for Inclusive Growth or Social Exclusion? J. Manag. Stud. 2012, 49, 785-812. 6486.2012.01044.x.

[12] Carta, M. Reimagining urbanism. In Creative, Smart and Green Cities for the Changing Times; List Lab: Trento,Italy, 2014.

[13] Shao, G.; Li, F.; Tang, L. Multidisciplinary perspectives on sustainable development. Int. J. Sustain. Dev. World Ecol. 2011, 18, 187-189. https://doi.org/10.1080/13504509.2011.572304. [14] Ghahramanpouri, A.; Lamit, H.; Sedaghatnia, S. Urban Social Sustainability Trends in Research Literature. Asian Soc. Sci. 2013, 9, 185-193.
DOI:10.5539/ASS.V9N4P185.

[15] Weingaertner, C.; Moberg, Å. Exploring social sustainability: Learning from perspectives on urban development and companies and products. Sustain. Dev. 2014, 22, 122-133.

https://doi.org/10.1002/sd.536.

[16] Suopajärvi, L.; Poelzer, G.A.; Ejdemo, T.; Klyuchnikova, E.; Korchak, E.; Nygaard, V. Social sustainability innorthern mining communities: A study of the European North and Northwest Russia. Resour. Policy 2016, 47, 6168.

https://doi.org/10.1016/j.resourpol.2015.11.00 $\underline{4}$. 